\title{
Big Five Personality dan Kinerja Keselamatan pada Karyawan
}

Siska Rachmawati, Nida Hasanati, Mohammad Shohib

Fakultas Psikologi, Universitas Muhammadiyah Malang siskarachm@gmail.com,nida@umm.ac.id, shohib@umm.ac.id

\begin{abstract}
Abstrak: Kasus kecelakaan kerja di Indonesia masih banyak terjadi. Ditemukan fakta bahwa $70 \%$ sampai $80 \%$ penyebab kecelakaan kerja disebabkan oleh kesalahan manusia. Kecelakaan kerja dapat dicegah dengan meningkatkan kinerja keselamatan, yaitu tindakan yang ditampilkan oleh individu dengan cara mematuhi dan mendukung prosedur keselamatan kerja. Faktor individu seperti karakteristik kepribadian dapat menjelaskan bagaimana para pekerja bersikap dan bertindak terhadap keselamatan di lingkungan kerjanya. Karakteristik kepribadian dalam penelitian ini mengacu pada big five personality. Tujuan penelitian yaitu untuk mengetahui pengaruh big five personality dengan kinerja keselamatan. Metode penelitian adalah pendekatan kuantitatif yang dilakukan pada 151 karyawan produksi. Instrumen penelitian menggunakan Big Five Inventory dan Safety Performance. Metode analisis yaitu analisis regresi berganda. Hasil penelitian menunjukkan bahwa pada dimensi agreeableness memiliki pengaruh positif terhadap kinerja keselamatan. Sedangkan dimensi neuroticism memiliki pengaruh negatif terhadap kinerja keselamatan. Sementara ketiga dimensi yang lain seperti extraversion, conscientiousness, dan openness tidak memiliki pengaruh terhadap kinerja keselamatan pada karyawan.
\end{abstract}

Kata kunci: Big Five Personality, Kinerja Keselamatan

Abstract: Work accident cases in Indonesia still occur. It was found that $70 \%$ to $80 \%$ of the causes of work accidents are caused by human error. Work accidents can be prevented by improving safety performance, i.e. actions performed by individuals by complying with and supporting work safety procedures. Individual factors such as personality characteristics can explain how workers behave and act towards safety in the work environment. Personality characteristics in this study refer to the big five personality. The purpose of this study is to determine the effect of big five personality on safety performance. The research method is a quantitative approach that is carried out on 151 production employees. The research instrument uses Big Five Inventory and Safety Performance. The method of analysis is multiple regression analysis. The results showed that the agreeableness dimension had a positive influence on safety performance. While the dimensions of neuroticism have a negative influence on safety performance. While the other three dimensions such as extraversion, conscientiousness, and openness have no influence on employee safety performance.

Keywords: Big Five Personality, Safety Performance

\section{PENDAHULUAN}

Meningkatnya permintaan pasar untuk memenuhi kebutuhan konsumen menyebabkan terjadinya perubahaan proses produksi, seperti penggunaan peralatan industri yang lebih canggih. Hal tersebut membuat perekonomian dalam bidang industri di Indonesia mengalami kemajuan 
yang pesat. Penerapan teknologi maju dalam proses produksi saat ini semakin intensif, sehingga efek samping berupa faktor fisik yang ditimbulkan juga semakin beraneka ragam diantaranya seperti suhu ekstrim, kebisingan, penerangan di tempat kerja, getaran, radiasi, dan gelombang elektromagnetik yang terdapat di lingkungan kerja (Soedirman, 2011).

Banyaknya kasus kecelakaan kerja yang terjadi di Indonesia ditunjukkan dengan angka kecelakaan yang masih tinggi. Berdasarkan data Badan Penyelenggara Jaminan Sosial (BPJS) Ketenagakerjaan, hingga akhir tahun 2015, telah terjadi kecelakaan kerja sebanyak 105.182 peristiwa dan sebanyak 2.375 peristiwa menyebabkan kematian (BPJS, 2016). Selain itu, pada tahun 2017 total peristiwa kecelakaan kerja yang terjadi sebesar 123.000 peristiwa dan menghabiskan biaya Rp 971 miliar, dan total tersebut bertambah sekitar 20 persen daripada tahun 2016 (Saut, 2018). Sedangkan pada tahun 2018, data BPJS Ketenagakerjaan mencatat sebanyak 175.000 kasus dan diketahui meningkat menjadi 40 persen dibandingkan tahun 2017. Berdasarkan data jumlah kecelakaan kerja dari situs Kementerian Pekerjaan Umum, sebesar 32 persen kecelakaan kerja terjadi pada sektor perusahaan konstruksi dan sektor perusahaan manufaktur. Selanjutnya, menyusul angka tersebut adalah kecelakaan pada sektor transportasi yaitu sebesar 9 persen, kehutanan 4 persen, dan pertambangan 2 persen (Suhendra, 2015).

Manusia secara naluriah akan menghindari terjadinya kecelakaan karena kecelakaan merupakan suatu kejadian yang merugikan. Kecelakaan dapat membuat seseorang mengalami hambatan, ketidakmampuan bahkan kematian, selain itu juga memerlukan biaya yang cukup besar (Winarsunu, 2008). Oleh karena itu tidak ada pekerja yang ingin mengalami kecelakaan ketika bekerja. Setiap orang tentu mengharapkan kesejahteraan dalam kehidupan pribadi maupun pekerjaannya.
Pelaksanaan kesehatan dan keselamatan kerja merupakan salah satu cara untuk melindungi pekerja, perusahaan, lingkungan, maupun masyarakat sekitar dari bahaya akibat kecelakaan kerja. Hal tersebut bertujuan untuk mengurangi penyakit dan kecelakaan akibat kerja, sehingga dapat meningkatkan efisiensi dan produktivitas kerja.

Menurut Winarsunu (2008) perilaku manusia atau karyawan dalam bekerja merupakan faktor utama yang dapat menyebabkan kemungkinan terjadinya kecelakaan kerja, dimana perilaku berbahaya (unsafety action) dipengaruhi oleh faktor-faktor manusia seperti keadaan emosi, kognisi, sikap, dan karakteristik perilaku umum yang lain. Faktor penyebab kecelakaan kerja tertinggi sebesar $70 \%$ sampai $80 \%$ disebabkan oleh kesalahan manusia atau human error, meskipun masih terdapat faktor lain penyebab kecelakaan kerja seperti faktor mekanik dan lingkungan (Winarsunu, 2008). Sementara itu, hasil penelitian Amponsah-Tawiah \& Adu (2016), menunjukkan bahwa perilaku keselamatan karyawan di tempat kerja berkaitan dengan norma kesopanan, iklim psikologis, sikap kerja, kepribadian individu, dan iklim keselamatan kerja.

Faktor penyebab kecelakaan kerja yang tinggi ialah kesalahan manusia, perilaku individu menjadi penyebab utama kecelakaan ditempat kerja. Peran manajemen dan karyawan merupakan upaya untuk menurunkan angka kecelakaan kerja. Menurut The Health and Safety Executive (HSE) pada tahun 2003 menyatakan bahwa tanpa kepemimpinan yang efektif, seseorang tidak dapat menampilkan kinerja keselamatan yang baik (dalam Lu \& Yang, 2010). Penelitian lain yang mengkaji mengenai kepemimpinan dalam keselamatan kerja, seperti Wu, dkk., (2008) mendefinisikan kepemimpinan yang aman (safety leadership) sebagai proses interaksi antara pemimpin dan bawahannya yang 
memberikan pengaruh untuk mencapai tujuan keselamatan organisasi dalam faktor organisasi dan individual.

Keberhasilan dalam usaha penerapan kesehatan dan keselamatan ditempat kerja tidak lepas dari peran karyawan tersebut. Upaya yang dapat dilakukan yaitu dengan meningkatkan kinerja keselamatan, atau dapat disebut dengan safety performance, yaitu perilaku pekerja kepada peraturan penerapan sikap keselamatan kerja yang telah berlaku dalam mengembangkan aspek keselamatan ditempat kerja (Neal \& Griffin, 2000).

Karyawan memiliki fungsi yang penting sebagai pelaku aspek keselamatan kerja. Kinerja keselamatan ialah suatu perilaku yang ditunjukkan secara langsung terkait dengan keselamatannya dalam bekerja. Kinerja keselamatan memiliki empat bentuk, terdiri dari penggunaan alat pelindung diri, berperan pada praktik kerja guna mengurangi risiko, mnegomunisasikan petunjuk tentang keselamatan dan kesehatan kerja, dan melakukan tanggungjawab serta hak pekerja (Burke, Sarpy, Tesluk, dan Smith, 2002). Pekerja yang mempraktikkan sikap kinerja keselamatan pada pekerjaannya, akan mengurangi risiko kecelakaan ditempat kerja (Griffin \& Neal, 2000).

Beberapa faktor yang mempengaruhi kinerja keselamatan adalah bahaya dan risiko kerja. Hal tersebut menunjukkan adanya hubungan yang positif dengan kinerja keselamatan pada aspek partisipasi keselamatan (Ford \& Tetrick, 2011). Faktor organisasi juga mempengaruhi, seperti kepemimpinan, beban kerja, manajemen organisasi, dan dukungan sosial juga dapat berpengaruh kepada kinerja keselamatan, baik dari segi aspek patuh terhadap keselamatan, maupun partisipasi keselamatan (Nahrang, dkk, 2011; Turner, $\mathrm{dkk}, 2012$ ).

Pada penelitian terdahulu mengenai kinerja keselamatan, ditemukan banyak hal yang dapat memengaruhi kinerja keselamatan seperti penelitian yang dilakukan oleh Yang, dkk., (2009) pada sektor kesehatan yang menemukan bahwa kepemimpinan berpengaruh terhadap peningkatan kinerja keselamatan. Selain itu, penelitian lain mengenai kinerja keselamatan pada bidang industri jasa transportasi dimana Huang, dkk., (2014) dalam penelitiannya menemukan pengaruh komunikasi terhadap kinerja keselamatan. Pembahasan lebih lanjut mengenai kinerja keselamatan di berbagai industri diperlukan karena menurut Wu, dkk., (2011) perbedaan bidang industri akan membuat hasil penelitian yang dilakukan lebih beragam.

Selain itu, terdapat penelitian lain mengenai kinerja keselamatan, seperti penelitian yang dilakukan oleh Sampson, dkk., (2014) menemukan hubungan antara stres kerja dengan kinerja keselamatan. Penelitian lain yang dilakukan oleh Wehbe, dkk., (2015) juga menemukan bahwa resiliensi membentuk kinerja keselamatan dalam suatu proyek konstruksi. Yuan, dkk., (2015) juga menemukan bahwa dukungan antar karyawan dan komitmen manajemen terhadap keselamatan memiliki pengaruh positif pada kinerja keselamatan yang dimediasi oleh keterlibatan kerja. Sementara faktor lain yang memengaruhi kinerja keselamatan ditunjukkan oleh penelitian Feng (2013) yang menemukan bahwa investasi keselamatan memiliki hubungan positif dengan kinerja keselamatan yang dimediasi oleh budaya keselamatan dan tingkat bahaya dari suatu proyek.

Pada konteks organisasi, iklim keselamatan yang positif akan meningkatkan perilaku aman termasuk juga keterlibatan pada aktivitas keselamatan (Cheyne, dkk., 1998 dalam Prinasti, 2018). Penelitian lain yang dilakukan Prabarini \& Suhariadi (2018) menunjukkan hasil bahwa iklim keselamatan kerja dan big five personality berpengaruh secara positif terhadap tindakan keselamatan. Sedangkan menurut Clarke (2013) dari segi 
kepemimpinan mengungkapkan bahwa kepemimpinan dengan gaya transaksional merupakan bagian dari aspek kepatuhan (safety compliance), berbeda dengan kepemimpinan dengan gaya transformasional adalah bagian dari asapek keterlibatan keselamatan (safety participation). Adapun Christian, dkk (2009) mengklasifikasikan anteseden dari perilaku keselamatan karyawan menjadi dua, yaitu faktor yang berkaitan dengan individu dan faktor yang berkaitan dengan situasi. Faktor yang berkaitan dengan individu terdiri dari karakteristik kepribadian, sikap kerja, dan pengetahuan individu. Sedangkan faktor yang berkaitan dengan situasi terdiri dari kepemimpinan dan iklim keselamatan kerja. Untuk itu, faktor individu yang dipilih untuk menjadi fokus dalam penelitian ini adalah karakteristik kepribadian.

Dalam berbagai kajian keselamatan kerja, karakteristik kepribadian turut berkontribusi dalam menjelaskan bagaimana para pekerja bersikap dan bertindak terhadap keselamatan di lingkungan kerjanya. Tipe kepribadian yang digunakan melihat pada model big five personality. Bentuk ini digunakan peneliti sebagai referensi guna mendalami dan menggambarkan keterkaitan tipe kepribadian dengan kinerja individu serta keterkaitan kepribdian dengan keterlibatan individu pada kecelakaan ditempat kerja (Clarke \& Robertson, 2005). Perilaku manusia dilatar belakangi oleh kepribadian (big five personality), hal tersebut sejalan dengan hasil penelitian yang dilakukan oleh (Prayitno, 2016) yang menunjukkan bahwa big five personality khususnya trait conscientiousness, agreeableness, dan neuroticism, memiliki pengaruh positif terhadap komitmen organisasi, budaya keselamatan, dan partisipasi keselamatan dapat memprediksi kepatuhan pekerja terhadap standard operating procedure (SOP) keselamatan kerja.
Penelitian yang dilakukan oleh Cellar, Nelson \& Bauer (dalam Jeffries, 2011) menunjukkan bahwa terdapat hubungan antara trait big five personality (openness, conscientiousness, extraversion, agreeableness, dan neuroticism) dengan keselamatan kerja. Pada dimensi openness terdapat hasil penelitian yang menyebutkan bahwa adanya hubungan yang positif antara openness dan keselamatan (Mahmudah, 2014). Sedangkan penelitian lain menunjukkan hasil bahwa adanya pengaruh positif antara dimensi openness terhadap kecelakaan, dan sebaliknya terdapat pengaruh negatif antara openness terhadap keselamatan (Clarke \& Robertson, 2005).

Sementara itu, pada dimensi conscientiousness memiliki pengaruh negatif terhadap kecelakaan yang terjadi pada individu, dan sebaliknya memiliki pengaruh positif terhadap perilaku keselamatan (Clarke \& Robertson, 2005). Hal tersebut sesuai dengan meta-analisis mengenai hubungan kepribadian dan kecelakaan kerja, ditemukan hasil bahwa terdapat hubungan negatif yang signifikan antara kecelakaan dengan tingkat conscientiousness yang rendah (Cellar, Nelson \& Bauer, dalam Jeffries 2011).

Pada dimensi extraversion beberapa penelitian menunjukkan bahwa adanya pengaruh positif antara extraversion terhadap kecelakaan kerja (Clarke \& Robertson, 2005). Hal tersebut sejalan dengan penelitian yang dilakukan oleh Powell yang menunjukkan hasil bahwa jumlah kecelakaan yang dialami oleh pekerja pabrik secara signifikan lebih tinggi untuk orang-orang ekstrovert (Clarke \& Robertson, 2005). Sedangkan dalam penelitian Mahmudah (2014) menunjukkan bahwa adanya hubungan positif antara dimensi extraversion dengan keselamatan.

Selain itu, pada dimensi agreeableness terdapat penelitian yang melibatkan pekerja pabrik di Amerika Serikat, David dan Mahoney menyebutkan bahwa adanya pengaruh negatif yang kuat 
antara kepercayaan dan altruisme terhadap keterkaitan individu pada kecelakaan (Clarke \& Robertson, 2005). Penelitian lain yang dilakukan oleh Clarke dan Robertson menunjukkan bahwa pada konteks kecelakaan kerja, tingkat agreeableness yang rendah merupakan prediktor dari keterlibatan kecelakaan (Clarke \& Robertson, 2005).

Sedangkan pada dimensi neuroticism, penelitian yang dilakukan oleh Clarke \& Robertson menunjukkan hasil bahwa terdapat pengaruh positif antara neuroticism terhadap keterlibatan dalam kecelakaan (Clarke \& Robertson, 2005). Hasil penelitian serupa yang dilakukan oleh Sutherland dan Cooper pada pekerja minyak lepas pantai juga menunjukkan bahwa individu dengan dimensi neuroticism tinggi lebih banyak mengalami kecelakaan kerja, memiliki tingkat ketidakpuasan yang lebih besar, serta memiliki tingkat kesehatan mental yang lebih rendah (Clarke \& Robertson, 2005).

Dalam lingkungan kerja terutama pada industri yang mempunyai risiko bahaya tinggi, faktor manusia menjadi sangat penting karena merupakan penentu keberlangsungan perusahaan dan juga sebagai tolak ukur bagaimana perusahaan benar-benar menerapkan program keselamatan yang ada. Ketika karyawan dapat menampilkan kinerja keselamatan, maka karyawan tersebut akan dapat bekerja dengan cara yang lebih aman. Perilaku atau tindakan keselamatan kerja seseorang mampu memprediksi dalam mengurangi kecelakaan kerja. Hal tersebut dapat berguna untuk seleksi maupun penempatan kerja pada karyawan. Melalui analisis hubungan antara kinerja keselamatan dan big five personality ini akan digambarkan perbedaan dari individu mana yang cenderung mudah mendapat kecelakaan kerja. Individu yang memiliki kinerja keselamatan yang baik tentunya akan membantu perusahaan atau organisasi dalam menciptakan budaya keselamatan kerja yang lebih positif. Hal inilah yang menjadi fokus utama bagi penulis untuk mengetahui bagaimana karyawan dapat bekerja secara aman dan hal apa saja yang dapat membantu untuk mencapainya. Penelitian ini dilakukan guna meneliti lebih lanjut apakah ada pengaruh kepribadian (big five personality) dengan kinerja keselamatan kerja pada karyawan.

\section{METODE}

Penelitian ini menggunakan penelitian kuantitatif. Menurut Sugiyono (2010), metode penelitian kuantitatif dapat diartikan sebagai metode penelitian yang berlandaskan pada filsafat positivisme, digunakan untuk meneliti pada populasi atau sampel tertentu, teknik pengambilan sampel pada umumnya dilakukan secara random, pengumpulan data menggunakan instrumen penelitian, analisis data bersifat kuantitatif/statistik dengan tujuan untuk menguji hipotesis yang telah ditetapkan. Adapun jenis penelitiannya adalah kuantitatif deskriptif, yaitu penelitian yang berusaha untuk menggambarkan dan menginterpretasi objek apa adanya (Best, 1982 dalam Darmawan, 2014).

Penelitian ini menggunakan pengambilan sampel dengan teknik nonprobability sampling. Non-probability sampling adalah jenis pemilihan sampel yang tidak dipilih secara acak (Darmawan, 2014). Metode yang digunakan dalam teknik pengambilan sampel ini adalah pendekatan purposive sampling yaitu teknik pengambilan subjek berdasarkan pertimbangan tertentu atau kriteria ditentukan peneliti (Sugiyono, 2010). Pertimbangan yang dimaksud oleh peneliti adalah berdasarkan pada syarat dan ketentuan yang telah peneliti tetapkan sebelumnya, antara lain: (1) karyawan produksi atau yang bekerja berhadapan dengan mesin; (2) berjenis kelamin laki-laki dan perempuan dengan rentang usia 18 sampai 40 tahun; (3) serta memiliki masa kerja minimal satu tahun. 
Pada penelitian ini, penulis menggunakan sampel sebanyak 151 karyawan produksi di salah satu perusahaan di Pasuruan. Hal tersebut didasarkan pada tabel Issac dan Michael yang menjelaskan bahwa dengan total populasi \pm 280 orang dengan taraf kesalahan sebesar 5\% maka jumlah sampel yang dibutuhkan sebanyak 155 orang (Sugiyono, 2010). Akan tetapi terdapat 4 skala yang tidak dapat diskoring sehingga terdapat 151 orang yang menjadi subjek dalam penelitian ini.

Penelitian ini terdiri dari dua variabel, yaitu variabel $\mathrm{X}$ (big five personality) dan variabel Y (kinerja keselamatan). Variabel bebas $(\mathrm{X})$ dalam penelitian ini adalah big five personality. Big five personality adalah bagaimana individu bertindak dan bersosialisasi dengan lingkungan sekitar yang dapat menjelaskan perilaku individu. Dimensi big five personality terdiri dari openness (X1), conscientiousness (X2), extraversion (X3), agreeableness (X4), dan neuroticism (X5).

Alat ukur yang digunakan untuk mengukur Big Five Personality adalah skala Big Five Inventory (BFI). Skala tersebut disusun berdasarkan teori Goldberg yang diadaptasi oleh Neila Ramdhani (2012) yang terdari 28 item.

Reliabilitas masing-masing dimensi dalam skala ini antara lain extraversion sebesar 0,73, agreeableness sebesar 0,76, conscientiousness sebesar 0,79 , neuroticism sebesar 0,75, dan openness sebesar 0,79. Jenis skala yang digunakan adalah skala likert dengan 5 pilihan jawaban (Sangat Tidak Sesuai, Tidak Sesuai, Netral, Sesuai, dan Sangat Sesuai).

Sedangkan kinerja keselamatan adalah hasil kerja yang dicapai individu dalam melakukan tugasnya sesuai dengan prosedur keselamatan kerja yang sudah ditentukan. Peneliti menggunakan alat ukur yang disusun oleh Griffin dan Neal (2002) yang terdiri dari 8 item. Skala tersebut terdiri dari dua aspek, yaitu safety compliance dan safety participant. Adapun reliabilitas sebesar 0,94 dan 0,89. Jenis skala yang digunakan adalah skala likert dengan 5 pilihan jawaban (Sangat Tidak Sesuai, Tidak Sesuai, Netral, Sesuai, dan Sangat Sesuai).

\section{Tabel 1. Indeks Validitas dan Reliabilitas} Skala Penelitian

\begin{tabular}{lcccc}
\hline \multicolumn{1}{c}{ Variabel } & $\begin{array}{c}\text { Jumlah } \\
\text { Item } \\
\text { yang } \\
\text { Diujikan }\end{array}$ & $\begin{array}{c}\text { Juml } \\
\text { ah } \\
\text { Item } \\
\text { Valid }\end{array}$ & $\begin{array}{c}\text { Indeks } \\
\text { Validitas }\end{array}$ & $\begin{array}{c}\text { Indeks } \\
\text { Reliabilitas }\end{array}$ \\
\hline $\begin{array}{l}\text { Big Five Inventory } \\
\text { Openness }\end{array}$ & 6 & 6 & $0,373-0,711$ & 0,786 \\
Conscientiousness & 6 & 6 & $0,293-0,732$ & 0,757 \\
Extraversion & 5 & 5 & $0,302-0,504$ & 0,638 \\
$\begin{array}{l}\text { Agreeableness } \\
\text { Neuroticism }\end{array}$ & 7 & 6 & $0,246-0,659$ & 0,707 \\
Kinerja & 4 & 4 & $0,325-0,680$ & 0,733 \\
Keselamatan & 8 & 8 & $0,300-0,751$ & 0,860 \\
\hline
\end{tabular}

Berdasarkan uji validitas dan reliabilitas hasil tryout yang telah dilakukan terhadap 60 subjek karyawan produksi di Pasuruan menunjukkan bahwa alat ukur Big Five Inventory (BFI) memiliki jumlah item valid sebanyak 27 item dari 28 item yang telah diuji statistik. Alat ukur tersebut memiliki indeks validitas yang berkisar antara 0,246 - 0,711 dengan indeks reliabilitas antara $0,638-0,786$. Selanjutnya pada alat ukur kedua yaitu Kinerja Keselamatan memiliki 8 item valid yang telah diuji coba. Alat ukur tersebut memiliki indeks validitas yang berkisar antara $0,300-0,751$ dengan indeks reliabilitas sebesar 0,860. Berdasarkan hasil uji validitas kedua skala penelitian tersebut didasarkan pada $\mathrm{r}$-tabel $=0,21$, dimana dapat diketahui bahwa jika r-hitung $>$ rtabel maka item tersebut dinyatakan valid. Selain itu, alat ukur Big Five Inventory (BFI) maupun alat ukur Kinerja Keselamatan keduanya dinyatakan reliabel karena memiliki indeks reliabilitas atau nilai Cronbach Alpha diatas 0,60 (Azwar, 2015).

Terdapat tiga tahapan dalam penelitian ini antara lain tahap persiapan, tahap pelaksanaan, dan tahap analisis data. Tahap persiapan, pada tahap ini peneliti mencari dan menentukan fenomena yang sering terjadi di Perusahaan, serta 
melakukan pendalaman materi melalui buku, jurnal, dan media elektronik yang berkaitan dengan variabel yang akan diteliti. Peneliti menggunakan alat ukur Big Five Inventory (BFI) dan Kinerja Keselamatan yang sudah diterjemahkan. Selanjutnya, peneliti meminta ijin untuk melakukan uji coba atau tryout alat ukur tersebut dengan tujuan mendapatkan nilai indeks validitas dan reliabilitas. Tryout dilakukan pada karyawan produksi dengan jumlah 60 karyawan yang bekerja di beberapa perusahaan berbeda di Pasuruan. Tryout tersebut dilakukan pada tanggal 19 April 2019 hingga 23 April 2019. Kemudian peneliti melakukan analisa data dengan menggunakan Statistical Package for Social Science (SPSS) 25 untuk mendapatkan item valid dan reliabel. Tahap pelaksanaan, pada tahap ini peneliti membagikan skala penelitian pada karyawan produksi dengan masa kerja minimal satu tahun. Skala penelitian atau alat ukur diberikan kepada subjek secara langsung dengan cara peneliti datang ke lokasi sekitar perusahaan; dan yang terakhir tahap analisis data, pada tahap ini peneliti menganalisa terhadap data yang telah diperoleh dengan menggunakan Statistical Package for Social Science (SPSS) 25. Dalam pengolahan data tersebut, peneliti menggunakan analisa regresi linier berganda dengan tujuan untuk mencari pengaruh dari dua atau lebih variabel terikat terhadap vaiabel bebas. Selanjutnya peneliti juga melakukan analisis serta menginterpretasikan data penelitian berdasarkan teori dan penelitian terdahulu yang relevan. Peneliti juga membuat kesimpulan berdasarkan penelitian yang telah dilakukan.

\section{HASIL}

Tabel 2. Deskripsi Subjek Penelitian

\begin{tabular}{lcc}
\hline $\begin{array}{c}\text { Kategori } \\
\text { Subjek }\end{array}$ & Frekuensi & Persentase \\
\hline Usia & & \\
$18-25$ tahun & 38 & $25,2 \%$ \\
$26-32$ tahun & 82 & $54,3 \%$ \\
$33-40$ tahun & 31 & $20,5 \%$ \\
\hline
\end{tabular}

\begin{tabular}{lcc}
\hline Total & 151 & $100 \%$ \\
\hline Jenis Kelamin & & \\
Laki-laki & 127 & $84,1 \%$ \\
Perempuan & 24 & $15,9 \%$ \\
\hline Total & 151 & $100 \%$ \\
\hline Status & & \\
Pernikahan & & \\
Menikah & 94 & $62,3 \%$ \\
Belum Menikah & 57 & $37,7 \%$ \\
\hline Total & 151 & $100 \%$ \\
\hline Pendidikan & & \\
Terakhir & & \\
SMP/sederajat & 3 & $2 \%$ \\
SMA/sederajat & 148 & $98 \%$ \\
\hline Total & 151 & $100 \%$ \\
\hline Lama Kerja & & \\
$1-3$ tahun & 62 & $41,1 \%$ \\
$4-7$ tahun & 79 & $52,3 \%$ \\
$8-10$ tahun & 10 & $6,6 \%$ \\
\hline Total & 151 & $100 \%$ \\
\hline
\end{tabular}

Hasil penelitian tersebut menunjukkan bahwa terdapat 151 responden penelitian dengan kategorisasi jenis kelamin laki-laki sebanyak 127 orang dan responden perempuan sebanyak 24 orang. Kemudian jika dilihat berdasarkan kategorisasi usia, terdapat responden dengan rentang usia $18-25$ tahun sebanyak 38 orang, responden dengan rentang usia 26-32 tahun sebanyak 82 orang, dan responden dengan rentang usia 33 - 40 tahun sebanyak 31 orang. Sedangkan, jika dilihat dari kategorisasi status pernikahan ditunjukkan bahwa responden menikah sebanyak 94 orang, dan responden belum menikah sebanyak 57 orang. Selanjutnya berdasarkan pendidikan terakhir responden, terdapat 3 orang responden memiliki pendidikan terakhir $\mathrm{SMP} /$ sederajat, dan terdapat 148 orang responden memiliki pendidikan terakhir SMA/sederajat. Selain itu, terdapat kategorisasi berdasarkan lama kerja responden, terdapat responden dengan rentang lama kerja $1-3$ tahun sebanyak 62 orang, responden dengan rentang lama kerja 4 - 7 tahun sebanyak 79 orang, dan responden dengan rentang lama kerja $8-10$ tahun sebanyak 10 orang. 
Tabel 3. Kategorisasi Data Penelitian

\begin{tabular}{lccc}
\hline \multicolumn{1}{c}{ Variabel } & $\begin{array}{c}\text { Jumla } \\
\text { h Item }\end{array}$ & $\begin{array}{c}\text { Mean } \\
\text { Hipoteti } \\
\mathbf{k}\end{array}$ & $\begin{array}{c}\text { Mean } \\
\text { Empiri } \\
\mathbf{k}\end{array}$ \\
\hline $\begin{array}{l}\text { Extraversion } \\
\text { Agreeableness }\end{array}$ & 5 & 15 & 18,97 \\
$\begin{array}{l}\text { Consientiousne } \\
\text { ss }\end{array}$ & 6 & 18 & 24,75 \\
Neuroticism & 4 & 18 & 22,58 \\
$\begin{array}{l}\text { Openness } \\
\text { Kinerja }\end{array}$ & 6 & 12 & 11,84 \\
Keselamatan & 8 & 24 & 20,90 \\
\hline
\end{tabular}

Berdasarkan tabel di atas dapat disimpulkan bahwa terdapat empat dimensi yang memiliki kecenderungan tinggi antara lain dimensi extaversion, agreeableness, conscientiousness, dan openness. Sedangkan dimensi neuroticism memiliki kecenderungan rendah.

\section{Uji Normalitas dan Linieritas}

Pada penelitian ini dilakukan uji normalitas dengan menggunakan uji skewness dan kurtosis, dan menunjukkan hasil kelima dimensi big five personality memiliki distribusi data normal. Hal tersebut dinilai berdasarkan dengan syarat Zskewness dan Zkurtosis terletak pada \pm 2 . Penentuan nilai Zskewness dihitung dengan cara membagi nilai skewness dengan Std. Error of Skewness. Sementara Zkurtosis membagi nilai kurtosis dengan Std. Error of Kurtosis. Nilai Zkewness dari dimensi extraversion -0,210, agreeableness -1,142, conscientiousness $-0,931$, neuroticism 1,471, openness 1,507 , kinerja keselamatan 0,867 . Sedangkann nilai Zkurtosis dari dimensi extraversion $-0,843$, agreeableness -0,942, conscientiousness 0,014, neuroticism 1,534, openness 1,536 , kinerja keselamatan 0,003. Berdasarkan nilai Zskewness dan Zkurtosis pada masingmasing variabel menunjukkan bahwa seluruh variabel tersebut normal karena terletak diantara \pm 2 .

Selanjutnya berdasarkan uji linieritas didapatkan hasil bahwa empat dimensi memiliki hubungan linieritas dengan kinerja keselamatan karena nilai signifikansi lebih dari 0,05. Akan tetapi dimensi neuroticism tidak terdapat hubungan yang linier dengan kinerja keselamatan karena signifikan kurang dari 0,05 .

Tabel 4. Uji Pengaruh antar Variabel secara Simultan

\begin{tabular}{cccc}
\hline $\begin{array}{c}\text { Kekuatan } \\
\text { Hubunga } \\
\text { n (R) }\end{array}$ & $\begin{array}{c}\text { R- } \\
\text { Squar } \\
\text { e }\end{array}$ & $\begin{array}{c}\text { Standar } \\
\text { d Error }\end{array}$ & $\begin{array}{c}\text { Signifikans } \\
\text { i Uji Anova }\end{array}$ \\
\hline 0,465 & 0,216 & 2,967 & 0,000 \\
\hline
\end{tabular}

Berdaasarkan tabel di atas, diketahui bahwa nilai R Square sebesar 0,216. Artinya $21,6 \%$ variabel big five personality berpengaruh terhadap kinerja keselamatan. Sedangkan sisanya $(100 \%-21,6 \%=$ $78,4 \%$ ) dipengaruhi oleh variabel yang tidak diteliti. Kemudian pada tabel tersebut juga diketahui nilai signifikansi (Sig.) sebesar 0,000 lebih kecil dari probabilitas 0,05 . Sehingga dapat disimpulkan bahwa terdapat pengaruh signifikan big five personality terhadap kinerja keselamatan pada karyawan.

Tabel 5. Uji Pengaruh antar Variabel secara Parsial

\begin{tabular}{lccc}
\hline \multicolumn{1}{c}{ Dimensi } & $\begin{array}{c}\text { Nilai } \\
\text { B }\end{array}$ & T & Sig. \\
\hline Extraversion & 0,061 & 0,701 & 0,485 \\
Agreeableness & 0,288 & 3,171 & 0,002 \\
Conscientiousness & 0,16 & 0,155 & 0,877 \\
Neuroticism & $-2,227$ & $-2,906$ & 0,004 \\
Openness & 0,114 & 1,276 & 0,204 \\
\hline
\end{tabular}

Setelah dianalisa menggunakan teknik uji regresi berganda dengan pilihan enter dapat diketahui dimensi extraversion memiliki nilai koefisien sebesar 0,061 dan nilai signifikansi sebesar 0,485 lebih dari 0,05 . Hal tersebut mengartikan bahwa hipotesis 1 pada penelitian ini ditolak karena tidak terdapat pengaruh terhadap kinerja keselamatan. 
Selain itu, dimensi agreeableness memiliki nilai signifikan sebesar 0,002 lebih kecil dari 0,05. Hal tersebut mengartikan bahwa hipotesis 2 pada penelitian ini diterima karena terdapat pengaruh terhadap kinerja keselamatan.
Sementara
pada
dimensi

conscientiousness memiliki nilai signifikan sebesar 0,877 lebih besar dari 0,05. Hal tersebut mengartikan bahwa hipotesis 3 pada penelitian ini ditolak karena tidak terdapat pengaruh terhadap kinerja keselamatan.

Sementara pada dimensi neuroticism memiliki nilai signifikansi sebesar 0,004 lebih kecil dari 0,05. Hal tersebut mengartikan bahwa hipotesis 4 pada penelitian ini diterima karena terdapat pengaruh terhadap kinerja keselamatan.

Sedangkan dimensi openness memiliki nilai signnifikan sebesar 0,204 lebih besar dari 0,05. Hal tersebut mengartikan bahwa hipotesis 5 pada penelitian ini diterima karena tidak terdapat pengaruh terhadap kinerja keselamatan.

Dapat disimpulkan bahwa terdapat pengaruh yang signifikan dari dimensi agreeableness dan neuroticism terhadap kinerja keselamatan. Sedangkan pada dimensi extraversion, conscientiousness, dan openness tidak ada pengaruh yang signifikan kinerja keselamatan pada karyawan.

Tabel 6. Distribusi Kontribusi Dimensi Big Five Personality dan Kinerja Keselamatan

\begin{tabular}{lccc}
\hline \multicolumn{1}{c}{ Dimensi } & $\begin{array}{c}\text { Standarized } \\
\text { Coefisien } \boldsymbol{\beta} \\
\text { (Koefisien } \\
\text { Regresi) }\end{array}$ & $\begin{array}{c}\text { Person } \\
\text { Correl } \\
\text { ation } \\
\text { (Koefi } \\
\text { sien } \\
\text { Korel } \\
\text { asi) }\end{array}$ & $\begin{array}{c}\boldsymbol{R} \\
\text { Squ }\end{array}$ \\
\hline Extraversion & - & 0,232 & \\
Agreeableness & 0,348 & 0,382 & \\
$\begin{array}{l}\text { Conscientious } \\
\text { ness }\end{array}$ & - & 0,297 & 0,216 \\
Neuroticism & $-0,230$ & $-0,281$ &
\end{tabular}

Openness 0,209

Setelah dilakukan

analisa menggunakan teknik uji regresi berganda dengan pilihan forward maka didapatkan hasil sebagai berikut:

(1) Pada hasil tabel sebelumnya menyatakan bahwa dimensi extraversion, conscientiousness, dan openness tidak memiliki signifikansi. Sehingga pada dimensi extraversion, conscientiousness, dan openness tidak memiliki pengaruh terhadap kinerja keselamatan maka angka pada standarized coefisien $\beta$ tidak ada.

(2) Pada hasil tabel sebelumnya menyatakan bahwa dimensi agreeableness memiliki signifikansi sebesar 0,002. Sehingga pada dimensi agreeableness memiliki pengaruh terhadap kinerja keselamatan dan dapat ditunjukkan pada standarized coefisien $\beta$ sebesar 0,348 dan angka pada person correlation sebesar 0,382. Maka ditemukan kontribusi pada dimensi agreeableness yaitu $0,348 \times 0,382=$ 0,133 atau sebesar $13,3 \%$.

(3) Pada hasil tabel sebelumnya menyatakan bahwa dimensi neuroticism memiliki signifikansi sebesar 0,004. Sehingga pada dimensi neuroticism memiliki pengaruh terhadap kinerja keselamatan dan dapat ditunjukkan pada standarized coefisien $\beta$ sebesar $-0,230$ dan angka pada person correlation sebesar -0,281. Maka ditemukan kontribusi pada dimensi neuroticism yaitu $-0,230 \times-0,281=$ 0,064 atau sebesar $6,5 \%$.

\section{PEMBAHASAN}

Kepribadian dapat dijelaskan sebagai karakteristik yang melekat pada diri individu, dimana karakteristik setiap individu berbeda-beda seperti perilaku, kognisi, dan emosi (Pourmazaherian, dkk., 2017). Karakteristik kepribadian yang digunakan penelitian ini mengacu model 
big five personality dengan lima dimensi diantaranya extraversion, agreeableness, conscientiousness, neuroticism, dan openness. Tujuan dari penelitian ini yaitu untuk mengetahui pengaruh antar dimensi big five personality terhadap kinerja keselamatan pada karyawan yang dianalisis menggunakan uji regresi berganda.

Berdasarkan hasil perhitungan uji pengaruh antar variabel dimensi kepribadian menunjukkan bahwa hanya dimensi agreeableness dan dimensi neuroticism pada big five personality yang memiliki pengaruh terhadap kinerja keselamatan pada karyawan. Data hasil penelitian menunjukkan bahwa pada dimensi agreeableness terdapat pengaruh positif terhadap kinerja keselamatan sebesar $13,3 \%$. Sementara pada dimensi neuroticism menjukkan terdapat pengaruh negatif dengan kinerja keselamatan yakni sebesar $6,5 \%$. Sedangkan ketiga dimensi yang lain pada penelitian ini seperti extraversion, conscientiousness, dan openness tidak memiliki pengaruh terhadap kinerja keselamatan pada karyawan.

Dimensi agreeableness berpengaruh secara positif terhadap kinerja keselamatan pada karyawan, yang berarti bahwa hipotesis 2 diterima dimana semakin tinggi tingkat agreeableness pada karyawan maka akan semakin tinggi pula kinerja keselamatan karyawan tersebut. Begitu juga sebaliknya, semakin rendah tingkat agreeableness pada karyawan maka akan semakin rendah pula kinerja keselamatan karyawan tersebut. Pengaruh dimensi agreeableness terhadap kinerja keselamatan sejalan dengan penelitian yang dilakukan oleh Nuringgani (2014) menunjukkan hasil bahwa individu dengan dimensi agreeableness yang positif maka akan memiliki keselamatan kerja yang positif pula. Karakteristik individu dengan dimensi agreeableness tinggi digambarkan dengan sifat yang ramah, murah hati, sikap yang baik, pemaaf, serta suka menolong (Feist \& Feist, 2010).
Individu

dengan

dimensi agreeableness yang tinggi ditandai dengan individu yang menunjukkan keramahan, kepercayaan, sikap terus terang, altruisme, kerelaan, kesederhanaan, dan hati yang lembut terhadap orang lain (Pervin, Cervone \& Jhon, 2005). Individu tersebut cenderung mengikuti dan mematuhi ketentuan-ketentuan di tempat kerja. Hal tersebut dilakukan dengan cara memperhatikan dan merawat peralatan kerja yang digunakan, selalu mengecek peralatan kerja sebelum dan sesudah digunakan supaya dirinya dan rekan kerja yang lain tidak celaka ketika menggunakan alat tersebut. Selain merupakan individu yang normatif dan patuh, mereka akan menunjukkan sikap kooperatif yang tinggi, empati, dan altruism atau suka menolong orang lain. Individu dengan altruism yang tinggi ditandai dengan melakukan tindakan pencegahan untuk menjaga dan memperhatikan keselamatan diri sendiri dan orang lain dalam bekerja, seperti mengatur ruangan kerja seaman mungkin agar ia dan rekan kerjanya dapat bekerja dengan aman (Mahmudah, 2014). Tindakan seperti itu yang dapat mengarahkan individu tersebut memiliki kinerja keselamatan yang cukup tinggi. Menurut Arthur \& Graziano (2006) individu dengan dimensi agreeableness yang tinggi selalu termotivasi untuk membantu dan memiliki rasa tanggung jawab terhadap keselamatan orang lain. Sedangkan individu dengan dimensi agreeableness yang rendah cenderung memilih bekerja tidak berkelompok ketika bekerja. Hal tersebut sesuai dengan hasil penelitian yang disampaikan oleh Mount, Barrick, dan Stewart bahwa dimensi agreeableness berpengaruh terhadap individu yang bekerja cenderung melibatkan hubungan interpersonal (Clarke \&Robertson, 2005).

Sementara itu, penelitian lain yang dilakukan Clarke \& Robinson menunjukkan hasil bahwa tingkat dimensi agreeableness yang rendah merupakan penyebab dari 
keterlibatan kecelakaan kerja pada seseorang di lingkungan kerja (Clarke \& Robertson, 2005). Individu dengan tingkat skor dimensi agreeableness yang rendah ditunjukkan dengan individu yang mengarah pada karakter individu yang sinis, kasar, penuh curiga, tidak kooperatif, tidak pemaaf, dan mudah terganggu (Pervin \& Daniel, 2012).

Berdasarkan dimensi dari kinerja keselamatan yaitu kepatuhan keselamatan (safety complience) dimana mengacu pada tindakan keselamatan yang dilakukan seseorang untuk mempertahankan lingkungan tetap aman. Kepatuhan pada peraturan keselamatan serta penggunaan alat pelindung diri. Sedangkan dimensi partisipasi keselamatan (safety participation) ditunjukkan seperti menghadiri acara terkait keselamatan kerja. Selain itu, individu yang memiliki kinerja keselamatan yang baik akan mengingatkan sesama rekan kerja untuk selalu berperilaku aman dan bergabung pada aktivitas keamanan.

Selanjutnya hasil analisis dimensi neuroticism pada penelitian ini berpengaruh secara negatif terhadap kinerja keselamatan atau hipotesis 4 diterima, yang berarti bahwa semakin rendah tingkat dimensi neuroticism pada karyawan maka akan semakin tinggi kinerja keselamatan karyawan tersebut. Begitu juga sebaliknya, semakin tinggi tingkat dimensi neuroticism pada karyawan maka akan semakin rendah kinerja keselamatan karyawan tersebut. Hasil penelitian tersebut sejalan dengan penelitian yang dilakukan oleh Clarke \& Robertson (2005) dan Pourmazaherian, dkk (2017) yang hasilnya menunjukkan adanya pengaruh negatif dari dimensi neuroticism terhadap kinerja keselamatan.

Penelitian yang dilakukan oleh Clarke \& Robertson menunjukkan hasil bahwa terdapat pengaruh positif antara neuroticism terhadap keterlibatan dalam kecelakaan. Hasil penelitian serupa yang dilakukan oleh Sutherland dan Cooper pada pekerja minyak lepas pantai juga menunjukkan bahwa individu dengan dimensi neuroticism tinggi lebih banyak mengalami kecelakaan kerja, memiliki ketidakpuasan yang lebih besar, serta memiliki tingkat kesehatan mental yang lebih rendah (Clarke \& Robertson, 2005). Berbeda halnya dengan hasil penelitian yang dilakukan oleh Prabarini (2018) yang menunjukkan hasil bahwa terdapat pengaruh positif dari dimensi negative emotionally terhadap perilaku keselamatan. Artinya semakin tinggi tingkat negative emotionality pada karyawan makan akan semakin tigi pula perilaku keselamatannya.

Faktor-faktor yang mendasari dimensi neuroticism terdiri dari kemarahan (anger), depresi (depression), kesadaran diri (selfconsciousness), kurangnya kontrol diri (immoderation), kerapuhan (vulnerability), dan kecemasan (anxiety) (Costa \& Widiger, 2002). Individu dengan dimensi neuroticism identik dengan adanya emosi negatif seperti rasa khawatir, tegang, dan takut. Individu yang dominan sifat pencemas menjadi mudah gugup dalam menghadapi masalah yang menurut orang pada umumnya merupakan hal sepele (Ramdhani, 2012). Neuroticism diartikan sebagai ketidakstabilan psikologis dan kondisi yang rentan untuk mengalami emosi negatif (Muris, 2007). Individu dengan dimensi neuroticism mudah mengalami stres, memiliki ide yang tidak realistis, mempunyai coping respond yang maladaptif, tertekan, gelisah, dan merasa tidak aman (Costa \& Widiger, 2002). Sedangkan individu dengan skor rendah memiliki kecenderungan bersikap tenang, bersemangat, dan merasa aman. Sementara individu dengan skor tinggi memiliki kecenderungan merasa tertekan, gelisah, dan tidak aman. Karakteristik orang dengan neuroticism tinggi adalah khawatir, gelisah, emosional, merasa tidak aman, dan tidak cakap (Pervin, 2005).

Individu dengan dimensi neuroticism tinggi akan cenderung mudah frustasi dan 
mengalami stres apabila apa yang dikerjakan tidak sesuai dengan apa yang diharapkan, serta merasa tertekan dan merasa tidak aman dalam bekerja. Selain itu juga memiliki kecemasan yang tinggi sehingga sifat-sifat tersebut dapat mengarahkan pada perilaku berbahaya karena mengabaikan kebijakan dan prosedur keselamatan serta praktik keselamatan dalam bekerja. Hal tersebut membuat aspek kepatuhan keselamatan (safety compliance) menjadi rendah karena kurangnya kepatuhan dalam penerapan prosedur keselamatan kerja. Emosi yang tidak terkontrol ketika mengalami kesulitan suatu pekerjaan juga dapat mengurangi fokus mereka dalam bekerja. Rendahnya partisipasi keselamatan (safety participation) ditunjukkan dengan kurangnya kontribusi pekerja untuk ikut mempromosikan program-program keselamatan kerja. Hal tersebut dapat mengganggu tindakan atau perilaku mereka dalam meningkatkan keselamatan kerja. Individu yang menerapkan aspek kinerja keselamatan pada pekerjaannya akan mengurangi risiko kecelakaan kerja yang terjadi.

Hasil penelitian ini juga menunjukkan bahwa dimensi extraversion tidak memiliki pengaruh terhadap kinerja keselamatan pada karyawan atau hipotesis 1 ditolak. Ketiadaan pengaruh pada dimensi extraversion ini selaras dengan hasil penelitian dari Lajunen (2001) dan Clarke \& Robertson (2005). Dalam penelitian Lajunen (2001) dimensi kepribadian yang dimoderasi oleh tipe pekerjaan membuktikan bahwaindividu dengan dimensi extraversion yang tinggi cendeerung menunjukkan tindakan tidak selamat saat melakukan pekerjaan yang memerlukan konsentrasi tinggi dan berkelanjutan, seperti air traffic control. Seseorang dengan skor tinggi pada dimensi extraversion memiliki karakter seperti menyukai bersosialisasi, aktif, suka berbicara, mengarah pada orang lain, optimis, perhatian, serta memiliki kasih sayang. Sementara itu, seseorang dengan skor rendah pada dimensi ini memiliki kecenderungan individu yang tertutup, kalem, tidak bersemangat, mengarah pada tugas, mudah merasa lelah, dan pendiam (Pervin \& Daniel, 2012).

Dimensi conscientiousness pada penelitian ini menunjukkan tidak adanya pengaruh terhadap kinerja keselamatan atau hipotesis 3 ditolak. Dalam penelitian Pusparini (2007) menunjukkan bahwa individu yang memiliki skor tinggi pada dimensi conscientiousness ditunjukkan dengan ciri-ciri individu yang berorientasi pada prestasi dan gigih sehingga dapat meningkatkan keterlibatan kerja pada karyawan. Sementara individu yang memiliki skor rendah cenderung lalai sehingga rentan terlibat dalam kecelakaan kerja. Ketiadaan pengaruh antara dimensi conscientiousness dengan kinerja keselamatan dalam penelian ini dapat dipengaruhi oleh faktor lain seperti faktor ekonomis, faktor organisasi, serta iklim keselamatan kerja. Hal tersebut sejalan dengan penelitian yang dilakukan oleh Prabarini (2018) yang menunjukkan hasil bahwa adanya pengaruh positif antara iklim keselamatan kerja terhadap keselamatan. Selain itu, adanya starndard operating procedure (SOP) yang diterapkan ketika bekerja oleh perusahaan dapat mempengaruhi keselamatan pada karyawan. Sehingga dimensi kepribadian ini tidak memiliki pengaruh terhadap keselamatan kerja.

Dimensi openness pada penelitian ini menunjukkan tidak adanya pengaruh terhadap kinerja keselamatan atau hipotesis 5 ditolak. Karakteristik dari dimensi openness menekankan pada seni dan keindahan. Oleh karena itu dimensi dalam penelitian ini tidak berpengaruh dengan kinerja keselamatan. Selain itu, individu dengan dimensi openness dicirikan dengan individu yang selalu ingin mengetahui suatu hal, cerdas, memiliki pengetahuan yang luas, 
imajinatif, serta cenderung tertarik pada seni (Barrick, dkk., 2012). Individu dengan ciri tersebut lebih menyukai pengetahuan mengenai keselamatan daripada mengenai perilaku keselamatan (Clarke \& Robertson,2005).

\section{KESIMPULAN}

Berdasarkan penelitian yang telah dilakukan, didapatkan hasil bahwa dari lima dimensi big five personality terdapat dua dimensi yang memiliki pengaruh terhadap kinerja keselamatan seperti dimensi agreeableness dan neuroticism. Pada dimensi agreeableness ditemukan adanya pengaruh positif dengan kinerja keselamatan sebesar 13,3\%. Berbeda pada dimensi neuroticisim yang menunjukkan adanya pengaruh negatif dengan kinerja keselamatan sebesar 6,5\%. Sedangkan dimensi extraversion, conscientiousness, dan openness tidak memiliki pengaruh terhadap kinerja keselamatan pada karyawan.

\section{IMPLIKASI}

Terdapat implikasi dari penelitian ini yaitu (1) bagi perusahaan diharapkan dapat mempertegas peraturan penerapan keselamatan kerja di lingkungan kerja. Hal tersebut bertujuan supaya karyawan dapat lebih menaati prosedur keselamatan kerja seperti menggunakan alat pelindung diri ketika bekerja. Selain itu, diharapkan dapat meminimalisir kecelakaan kerja dengan cara mengurangi kecenderungan dimensi kepribadian yang memiliki pengaruh negatif terhadap keselamatan kerja seperti melalui pelatihan atau memberi pengetahuan (safety knowladge) kepada karyawan mengenai pentingnya keselamatan kerja. Apabila pengetahuan mengenai keselamatan bertambah, maka kinerja keselamatan juga akan meningkat; (2) bagi peneliti selanjutnya disarankan untuk melanjutkan penelitian dengan menggunakan populasi yang berasal dari beberapa organisasi supaya didapatkan gambaran mengenai kinerja keselamatan secara luas. Selain itu diharapkan dapat menambah variabel-variabel lain yang diduga memiliki pengaruh terhadap kinerja keselamatan pada karyawan.

\section{DAFTAR PUSTAKA}

Amaliyah, Nurul. (2017). Hubungan antara iklim keselamatan kerja dengan kinerja keselamatan pada karyawan perusahaan food and beverage di Pasuruan. Skripsi, Program Strata 1 Universitas Muhammadiyah Malang, Malang.

Amponsah-Tawih, K., \& Adu, M.A. (2016). Work preasure and safety behaviours among health workers in Ghana: the moderating role of management commitment to safety. Safety and Health at Work, 7, 340-346.

Alwisol. (2009). Psikologi kepribadian. Malang: UMM Press.

Arthur, W., \& Graziano, W. G. (2006). The Five-Factor Model, Conscientiousness, and Driving Accident Involvement. Journal of Personality.

Azwar, S. (2015). Metode penelitian. Yogyakarta: Pustaka Pelajar.

Barrick, M. R., Mount, M. K., \& Li, N. (2012). The theory of purposeful work behavior: The role of personality, Job Characteristics, and Experienced Meaningfulness. The Academy of Management Review.

Bangun, Wilson. (2012). Manajemen sumber daya manusia. Bandung: Erlangga.

Brondino, M, Silva S. A., \& Pasini, M. (2013). Authentic leadership and its relationship with risk perception and 
safety climate. Safety Science, 50, 1847-1856.

Burke, M. J., Sarpy, S. A., Tesluk, P. E., \& Smith-Crowe, K. (2002). General safety performance: A test of a grounded theoretical model. Personnel Psychology, 55, 429-457.

Clark, S. \& Robertson, I.T. (2005). A metaanalytic review of the big five personality factors and accident involvement in occupational and nonoccupational. Journal of Organizational and Occupational Psychology, 78, 355376.

Clarke, S. (2013). Safety leadership: A meta-analytic review of transformational and transactional leadership styles as antecedents of safety behaviours. Journal of Occupational and Organizational Psychology, 86, 22-49.

Christian, M.S., Bradley, J.C., Wallace, J.C., \& Burke, M.J. (2009). Workplace safety: A meta-analysis of the roles of person and situation factors. Journal of Applied Psychology, 4, 1102-1127.

Costa, P.T., \& Widiger, T.A. (2002). Personality disorder and the five-factor model of personality (2nd ed). Washington: American Psychological Association.

Darmawan, D. (2014). Metode penelitian kuantitatif. Bandung: PT. Remaja Posdakarya.

Feng, Y. (2013). Effect of safety investments on safety performanceof building projects. Safety Science, 59, $28-45$.
Feist, J., \& Feist, G. J. (2010). Teori kepribadian (buku 2) edisi ketujuh. Jakarta: Salemba Humanika.

Ford, T. M., \& Tetrick, E. L. (2011). Relations among occupational hazards, attitudes, and safety performance. Journal of Occupational Health Psychology, 16, (1), 48-66.

Friedman, H. S., \& Miriam W. S. (2006). Kepribadian: teori klasik dan riset modern (personality: classic theories and modern reasearch). Jakarta: Penerbit Erlangga.

Griffin, M. A., \& Neal, A. (2000). Perceptions of safety at work: Framework from linking safety climate to safety performance, knowledge, and motivation. Journal of Motivational Health Psycholoy, 5, (3), 347-358.

Hadipoetra, Sajidi. (2014). Manajemen komprehensif keselamatan kerja. Jakarta: Yayasan Putra Tarbiyyah Nusantara.

Huang, Y., Zohar, D., Lee, J., \& Robertson, M. (2014). A mediation model linking dispatcher leadership and work ownership with safety climate as predictors of truck driver safety performance. Journal of Applied Ergonomics.

Jeffries, F.L. (2011). Predicting safety related attitudes in the workplace: the influence of moral maturity and emotional intellegence. Institute of Behavioral and Applied Management.

Jumlah Kecelakaan Kerja di Indonesia Masih Tinggi. (2016, 11 Januari). BPJS Ketenagakerjaan (online). Diakses pada tanggal 25 Januari 2019 dari https://www.bpjsketenagakerjaan.go.id 
/5769/Jumlah-kecelakaan-kerja-diIndonesiamasih-tinggi.html.

Lajunen, T. (2001). Personality and accident liability: Are extraversion, neuroticism and psychoticism related to traffic and occupational fatalitities. Personality and Individual Differences, 13, 1365-1373.

Lu, C. \& Yang, C. (2010). Safety leadership and safety behaviour in container terminal operations. Journal of Safety Science, 48, 123-134.

Mahmudah, A.D. (2014). Hubungan antara sikap terhadap keselamatan kerja dan kepribadian. Skripsi, Program Strata 1 Universitas Muhammadiyah Malang, Malang.

Muris, P. (2007). Normal and abnormal fear and anxiety in children and adolescant. UK: Elseiver.

Nahrgang, J. D., Morgeson, F. P., \& Hofmann, D. A. (2011). Safety at work: A meta-analytic investigation of the link between job demands, job resources, burnout, engagement, and safety outcomes. Journal of Applied Psychology, 96, 71-94.

Nurfadhilah, Ilmi., M. Indrayadi Rafie. (2014). Pelaksanaan program keselamatan dan kesehatan kerja (k3) pada proyek pembangunan terminal penumpang bandara supadio Pontianak. Jurnal Mahasiswa Teknik Mesin Universitas Tanjungpura, 2, (2), 1-6.

Prayitno, Hadi. (2016). Big five personality sebagai prediktor dalam model kepatuhan terhadap standard operating procedure keselamatan kerja di industri konstruksi Ppasuruan. Skripsi, Program Strata 1 Universitas Airlangga, Surabaya.
Pervin, L. A., Cervone, D., \& Oliver, P. J. (2012). Psikologi kepribadian: teori dan penelitian (edisi ke-9). Jakarta: Kencana Prenada Media Group.

Pervin, A. L \& Daniel C. (2012). Kepribadian: teori dan penelitian, buku 2 (Ed.10). (Ter. Aliya Tusyani dkk). Jakarta: Salemba Humanika.

Pervin, Cervonde, Jhon. (2005). Personality theory and research (9th ed). New York: Jhon Willey \& Sons, Inc.

Pourmazaherian, M., Baqutayan, S.M., \& Idrus, D. (2017). The role of the big five personality factors on accident: A case of aaccident in construction industries. Journal of Science, Technology, and Innovation Policy, 3, (2).

Prabarini, Puspa., \& Fendy Suhariadi. (2018). Iklim keselamatan kerja dan big five personality sebagai prediktor perilaku keselamatan karyawan. Jurnal Psikologi Teori dan Terapan, 9, (1), 116.

Pratama, D. A., dkk. (2012). Pengaruh kepribadian berdasarkan the big five personality terhadap kepuasan kerja karyawan hotel. Jurnal Gema Aktualita, $1,(1)$

Prinasti, V. G. (2018). Hubungan safety climate dan stress kerja dengan safety performance pada karyawan PT. Waskita karya proyek jembatan musi. Skripsi, Program Strata 1 Universitas Airlangga, Surabaya.

Ramdhani, N. (2012). Adaptasi bahasa dan budaya inventori big five. Jurnal Psikologi, 39, 189-207.

Sawacha E., Naoum, S., \& Fong, D. (1999). Factors affecting safety performance on construction sites. International Journal 
of Project Management, 17, (5), 309315.

Sampson, J. M., Dearmond, S., \& Chen, P.Y. (2014). Role of safety stressors and social support on safety performance. Safety Science, 64, 137-145.

Saut, P. D. (2018). Angka Kecelakaan Kerja RI Meningkat ke 123 Ribu Kasus di 2017. Detik Finance (online). Diakses pada tanggal 25 Januari 2019 dari https://finance.detil.com/moneter/d3853101/angka-kecelakaan-kerja-rimeningkat-ke-123-ribu-kasus-di-2017.

Soedirman. (2011). Higiene perusahaan. Magelang: Justika Teknika.

Sugiyono. (2010). Metodologi penelitan pendidikan pendekatan kuantitatif, kualitatif, dan R\&D. Bandung: Alfabeta.

Suhendra, Zulfi. (2015). Kecelakaan Kerja Sektor Konstruksi Paling Tinggi di Indonesia. Liputan6 (online). Diakses pada tanggal 25 Januari 2019 dari https://www.liputan6.com/bisnis/read/ 2387230/kecelakaan-kerja-sektorkonstruksi-paling-tinggi-di-indonesia.

Stuhlmacher, A. F., Briggs, A. L., \& Cellar, D. F. (2009). Workplace safety and personality. Dalam P. J. Corr, \& G.
Matthews (Eds), The Cambridge Handbook of Personality Psychology (764-779). United Kingdom: Cambridge University Press.

Wehbe, F. Hattab, M.A., \& Hamzeh, F. (2016). Exploring associations between resilience and construction safety performance in safety networks. Safety Science, 82, 338-351.

Winarsunu, Tulus. (2008). Psikologi keselamatan kerja. Malang: UMM Press.

Wu, T., Chang, S., Shu, C., Chen, C., \& Wang, C. (2011). Safety leadership and safety performance in petrochemical industries: The mediatiang role of safety climate.

Yang, C., Wang, Y., Chang, S., Guo, S., \& Huang, M. (2010). A study on the leadership behavior, safety culture, and safety performance of the healtcare industry. World Academy of Science, Engineering and Technology L: Educational and Psychological Sciences, 2, 94-87.

Yuan, Z., Li, Y., \& Tetrick, L.E. (2015). Job hindrances, job resources, and safety performance: The mediating role of job engangement. Applied Ergonomic, 51, 163-171. 